\title{
Value and Momentum in the Cross Section of Housing Market Returns of New Zealand
}

\author{
By Daniel Dunstan* \\ AND \\ JINJI $\mathrm{HAO}^{\dagger}$ \\ November 9, 2021
}

\begin{abstract}
This paper examines if there are value and momentum effects in the New Zealand housing market across different regions. It is found that the short-term momentum effect exists with the winner regions in the past year outperforming the loser regions in the following year by 2.06\%, mainly from capital gains, after adjusting for the market risk. The house returns exhibit long-term reversal with the winner regions in the last six years underperforming the loser regions in each of the next eight years due to lower capital gains. A value effect is present with regions with high rent-price ratios outperforming those with low rent-price ratios in each of the next seven years due to persistent higher rental yields. However, both the reversal effect and value effect can be explained by the market risk.

JEL: G11, G12, R32

Keywords: Momentum, Value, Rental Yield, Capital Gains, Housing Market, New Zealand
\end{abstract}

If the Auckland housing market has larger capital gains than Wellington housing market in the last year, can we expect Auckland house prices to continue to outperform Wellington over the next year? What would we expect to happen if Auckland has experienced a larger house price appreciation over the last 5 years? If Otago has a higher rent-price ratio than Auckland at present, will Otago outperform Auckland over the next year or several years?

* New Zealand Treasury. Email: daniel.dunstan2@gmail.com.

$\dagger$ School of Economics and Finance, Victoria University of Wellington. Email: jinji.hao@vuw.ac.nz. 
There has been extensive research into the momentum, reversal, and value effects across asset classes such as stocks, currencies, bonds, and commodities. Assets that have performed well in the last six to twelve months tend to outperform those that did poorly over the next six to twelve months. Stocks that have performed well in the last three to five years tend to underperform those that did poorly in the following years. Stocks with relatively higher earnings-price ratios (value stocks) tend to outperform those with relatively lower earnings-price ratios (growth stocks) in the future.

The leading economic explanation for the short-term momentum and longterm reversal is based on investors' underreaction and overreaction to news, respectively (Barberis, Shleifer, and Vishny, 1998). On the one hand, due to investors' conservatism bias, when receiving a piece of news, they do not adjust their beliefs enough. The information contained in the news is then incorporated into the prices gradually, which gives rise to a shortterm momentum. On the other hand, due to investors' representativeness bias, when receiving a series of news pointing in the same direction, they extrapolate the pattern and believe that the same outcome is more likely next time. Investors overreact, pushing the asset prices too high, but these prices return to the mean on average later, which gives rise to a long-term reversal. We are interested in whether these phenomena of underreaction and overreaction may also happen in the housing markets by examining the momentum and reversal effects in the house prices. There has been a significant literature in studying the momentum in real estate investment trusts (REITs), but there are very few studies of the momentum and reversal of residential real estate. ${ }^{1}$ This is particularly the case for the New Zealand market.

The motivation for why the valuation ratios such as dividend-price ratio, earnings-price ratio, or book-market ratio may be positively associated with higher future returns is usually based on the present-value identity from Campbell and Shiller (1988)

$$
d p_{t}=k+\sum_{j=1}^{\infty} \rho^{j-1} E\left[r_{t+j}\right]-\sum_{j=1}^{\infty} \rho^{j-1} E\left[\Delta d_{t+j}\right],
$$

\footnotetext{
${ }^{1}$ In a four-factor asset pricing model for housing returns proposed by Beracha and Skiba (2013), a psychologically motivated momentum factor is included.
} 
where $d p_{t}$ is $\log$ dividend-price ratio at time $t, r_{t+j}$ is the return at time $t+j$, and $\Delta d_{t+j}$ is the dividend growth rate at time $t+j . k$ is a constant, and $\rho$ is typically estimated at 0.96 . This identity implies that a higher dividendprice ratio at present is associated with either higher expected future returns or lower expected future cash flow growth rates. So there is a chance that the dividend-price ratio predicts future returns. This is indeed the case in the stock markets. The rent-price ratio for houses is analogous to the dividend-price ratio for stocks, and a similar present-value identity holds. Therefore, we are interested in whether the rent-price ratio predicts future housing returns as well by examining whether a value effect exists in the housing market.

This paper contributes to the literature by examining the New Zealand housing market for evidence of momentum, reversal, and value effects in the cross section of regional housing markets returns. We are interested in if regions with larger house price increases will outperform regions with lower house price increases and if regions with higher rent-price ratios will earn higher returns in the future.

Using housing data from January 1992 to January 2019, we begin by examining the cross-sectional momentum and reversal effects. To do this we implement a portfolio formation analysis that ranks regions based on either past capital gains or past total returns, which include rental yields. Each month we rank the regions and construct quartile portfolios. We then track the future performance of each quartile portfolio in the following years.

First, we find that when sorting regions based on the past twelve-month returns, either capital gains or total returns, there is a one-year momentum effect. When sorting regions based on capital gains, we find that the portfolio of past winners outperforms the portfolio of past losers by an average up-minus-down (UMD) return of $2.46 \%$ next year, which is statistically significant at the $1 \%$ level. We also test the economic and statistical significance of the risk-adjusted returns. In a regression of UMD returns against the housing market risk premium within the Capital Asset Pricing Model (CAPM), the abnormal UMD return (alpha) is $2.07 \%$ per year and is significant at the $5 \%$ level. $^{2}$ Therefore, the one-year momentum cannot be

\footnotetext{
${ }^{2}$ The alpha is $1.93 \%$ per year and is significant at the $10 \%$ level if the sorting is based
} 
explained by the market risk.

Second, we find that when sorting regions based on the past six-year returns, either capital gains or total returns, there is a reversal effect. This effect is persistent up to eight years. We find that the portfolio of past losers outperforms the portfolio of past winners by average returns of $1 \%-4 \%$ in each of next eight years, which are statistically significant. However, these returns are likely due to a higher housing market risk, with the alpha of the UMD returns being statistically insignificant after adjusting for the market risk using CAPM.

By decomposing the future returns of the quartile portfolios, we find that both momentum and reversal effects are driven solely by capital gains. Regions that performed poorly in the past twelve months earn a slightly higher rental yield next year, which nevertheless is statistically significant. Note that this is in the opposite direction for momentum. For reversal, however, the differences in the rental yields in the following years are mostly statistically insignificant. These are similar to the previous findings for stocks where momentum and reversal are driven by stock prices instead of dividends.

We next test the presence of a value effect using a similar portfolio formation technique. Instead of sorting regions based on past returns, we sort them based on the rent-price ratios observed in the previous month. We find that a relatively high current rent-price ratio strongly and positively predicts higher future total returns, which are largely due to higher future rental yields. We find that the portfolio of regions with the highest rentprice ratios outperforms the portfolio of regions with the lowest rent-price ratios by average high-minus-low (HML) returns of $2 \%-3 \%$ in each of next eight years, which are statistically significant. However, like the reversal effect, these returns are likely due to a higher housing market risk, with the alpha of the HML returns being statistically insignificant after adjusting for the market risk.

This paper is structured as follows. In the next section we review the relevant literature. We describe the data in Section 3 and explain the method used to identify momentum, reversal, and value in Section 4. In Section 5 on total returns. 
we present the empirical results. In Section 6 we discuss the shortcomings of our findings and their applications. Section 7 concludes the paper.

\section{Literature Review}

\section{A. Momentum and Value in Other Asset Classes}

There exists a large body of research on both momentum and value factors. Jegadeesh and Titman (1993) first document a momentum effect in stocks. They find that a strategy that buys past winners and sells past losers generates an abnormal return of around $1 \%$ per month over a threeto twelve-month time horizon. The discovery of this anomaly has led to the implementation of various momentum strategies in the financial markets around the world. Chan, Jegadeesh, and Lakonishok (1996) further investigate momentum in stocks. They find that when the U.S. stocks are sorted by their past six-month returns and placed into decile portfolios from 1977 to 1993, the past winners beat the past losers over the next six to twelve months before the effect dissipates. They attribute the momentum effect to the continued positive (negative) earnings surprises to past winners (losers), which generate abnormal returns around the announcements.

Looking at longer horizons, De Bondt and Thaler (1985, 1987) find that portfolios of losers over the past three to five years outperform portfolios of past winners. They use the U.S. stock data from 1926 to 1982 to form their decile portfolios based on past cumulative average returns. De Bondt and Thaler argue that their findings are due to investors' overreaction to unexpected and dramatic news events.

Fama and French (1992) find that in the U.S. market stocks with higher book-market ratios earn higher risk-adjusted returns than stocks with low book-market ratios for the 1963 to 1990 period. In addition to the bookmarket ratios for explaining the cross-sectional stock returns, Basu (1983) finds that in the U.S. market common stocks with higher earnings-price ratios earn higher risk-adjusted returns than common stocks with low earningsprice ratios during the sample periods 1957 to 1971 and 1963 to 1980.

Fama and French (1996) find both momentum and long-term reversal in the U.S. stocks for the periods of 1931 to 1963 and 1963 to 1993 . When sorting stocks based on past twelve-month returns, skipping the most recent 
month, they find that winners outperform losers in both periods, although the effect is stronger in the 1963 to 1993 period. Sorting stocks based on the past five-year returns, skipping the most recent year, they find that in both periods past losers outperform past winners. Using their three-factor model they can explain long-term reversal by noting that the value betas are increasing as we go from the winner portfolios to the loser portfolios. The three-factor model, however, cannot explain momentum. The value betas go in the wrong direction. In both cases there are no differences in market betas, and the size betas are U-shaped.

Asness, Moskowitz, and Pedersen (2013) go beyond the U.S. equity markets and provide evidence that both momentum and value factors exist globally across equities, currencies, bonds, and commodities. They sort each asset class into three groups and report the high-minus-low returns. For momentum, they sort each asset class into groups by their past twelvemonth cumulative raw returns, skipping one month. For value, they sort stocks and indices based on their past six-month book-market ratios, sort commodities based on the negative past five-year spot returns, sort currencies based on the negative past five-year returns on the exchange rates, and sort bonds based on the five-year changes in the yields of 10-year bonds. They find that from 1974 to 2011 for stocks, from 1978 to 2011 for indices, from 1980 to 2011 for currencies, from 1982 to 2011 for government bonds, and from 1972 to 2011 for commodities, there is consistent performance in both value and momentum and their combinations across the markets and asset classes. They also show that value and momentum strategies are negatively related over the asset classes.

\section{B. Momentum and Value in the Real Estate Markets}

The prominence of cross-sectional momentum within various asset classes has first led to many studies into REITs. Liu and Mei (1992) and Mei and Liu (1994) find that variations in real estate investment trusts (REITs) expected excess returns are predictable based on changes in business conditions. Chui, Titman, and Wei (2003) study the cross section of expected REIT returns. Using American REITs from 1984 to 2000, they find cross-sectional predictability of REIT returns that is caused by strong momentum effects. Derwall et al. (2009) also find momentum in REIT 
returns. Moreover, they find REIT momentum strategies produce larger returns compared to common stock momentum strategies. Hung and Glasock (2008) find positive correlations between dividend yields and momentum returns and document that past REIT winners have much higher dividend yields than past losers, explaining the momentum effect found in REITs.

For returns to residential real estate in the U.S., a momentum factor is present in an asset pricing model proposed by Beracha and Skiba (2013), together with a market factor, a factor derived from income growth, and a factor derived from land supply elasticity. For the commercial real estate, Beracha and Downs (2015) find that future returns are positively correlated with the relative return momentum, which is robust to risk adjustment.

Just like the earnings-price ratios can be used to measure value in stocks, the rent-price ratio is used to study value in real estate. The rent-price ratio has also been analysed in several recent papers. Plazzi, Torous, and Valkanov (2010) find that the rent-price ratio is able to explain a large portion of variations in expected returns in apartments, retail properties, and industrial properties. Gallin (2008) shows that the rent-price ratio predicts changes in real prices over four-year periods, but is unable to predict changes in real rents over the same periods. Using office and retail properties return data for the United States and some Asia Pacific cities, Addae-Dapaah et al. (2013) find that value portfolios outperform growth portfolios. Moreover, their analyses generally do not support the risk-based explanation for the value premium. For the commercial real estate, Beracha and Downs (2015) also find that future returns are positively correlated with the value effect, which is robust to risk adjustment. Using market-adjusted cap rates to classify individual properties, Beracha, Downs, and MacKinnon (2017) find evidence of a strong value effect in real estate: High-cap-rate properties exhibit higher returns, outperform on a risk-adjusted basis.

We contribute to this literature by examining the momentum, reversal, and value effects in the New Zealand regional residential real estate. The novelty of our methodology is that we decompose these effects into the capital gains and rental yields. 


\section{The Housing Market in New Zealand}

The economic literature in the New Zealand housing markets has examined the latent factor structures in the house prices across regions or cities. Hall, McDermott, and Tremewan (2006) find that regional house price cycles differ considerably from the national cycle and across the regions. Grimes, Holmes, and Tarrant (2010) isolate one non-stationary factor affecting all regions of New Zealand based on a principal component analysis. GreenawayMcGrevy and Phillips (2016) find that housing bubbles spread from Auckland to other urban centres within New Zealand. Greenaway-McGrevy, Grimes, and Holmes (2019) find that the 16 cities considered across Australia and New Zealand possess a single non-stationary factor that affects real house prices in all the cities.

In contrast, this paper studies the factors of New Zealand housing markets from a finance perspective. We assume the existence of a market risk factor as in CAPM. We examine the existence of additional momentum, reversal, and value factors. We find that while the reversal and value effects can be explained by the market risk factor, the momentum effect cannot be explained the market risk factor.

\section{Data Description}

We describe the data sources in this section.

\section{A. Median House Price Data}

We gathered monthly median house price data for each of the 16 regions of New Zealand from January 1993 to January 2019. The data are collected from the Real Estate Institute of New Zealand (REINZ). REINZ's median house price is based on all the transactions within a region in a particular month. A transaction is included when the sale becomes unconditional, which means the data series reveal market movements quickly. Only sales within the corresponding month will contribute to that month's median price.

All types of houses, from small apartments to mansions, are included in the data. We have chosen to use the median price instead of the mean price 
to control for outliers. The average price in regions like the West Coast is very volatile, so the median price helps mitigate the problem in such cases.

Different from the stock prices, there is a substantial seasonality in the house prices, which may give rise to the price momentum or reversal mechanically. However, the data used in this article are seasonally adjusted, which provide an accurate representation of how prices move month by month. So the price patterns documented in this article are not due to seasonality.

\section{B. Mean Monthly Rent Data}

We collected the monthly data of mean rent per week from the Tenancy bond database of the Ministry of Business, Innovation, and Employment (MBIE). The data start from January 1993 and end on January 2019. The bond data measure the mean weekly rent of new bonds by private landlords. It is required under the Residential Tenancies Act (RTA) for every landlord to lodge their bonds with the MBIE. The data capture only the rents of new bonds instead of the rents paid by all tenants. This is useful since it is rare for the existing rental agreements to change frequently. By only considering new bonds the data better reflect the movements in regional rent levels.

\section{Capital Gains and Rental Yield}

Given the house price $P_{t}$ and the rent per week $R_{t}$ for each month $t$, the total return for month $t$ is calculated as

$$
r_{t}=\frac{P_{t}+R_{t} \times 30 / 7}{P_{t-1}}-1 .
$$

The total return for a year is the compounded monthly returns within the year. The capital gain for each month $t$ is calculated as

$$
r c_{t}=\frac{P_{t}}{P_{t-1}}-1 .
$$


The capital gain for a year ending at month $t$ is calculated $\mathrm{as}^{3}$

$$
r c_{t}=\frac{P_{t}}{P_{t-12}}-1 .
$$

The rental yield for each month $t$ is calculated as

$$
r y_{t}=\frac{R_{t} \times 30 / 7}{P_{t-1}} .
$$

The rental yield for a year is the average monthly rental yield within the year multiplied by 12 .

\section{Region Description}

Since we are interested in analysing momentum and value factors in the cross section of New Zealand housing markets, we choose to study the housing markets in sixteen regions of New Zealand. A region is a territorial authority area governed by a regional council or territorial authorities known as unitary authorities. The sixteen regions are Auckland, Bay of Plenty, Canterbury, Gisborne, Hawke's Bay, Manawatu, Marlborough, Nelson, Northland, Otago, Southland, Tasman, Waikato, Wellington and West Coast.

\section{E. Summary Statistics}

Table 1 reports the statistics of the housing market returns of the sixteen regions of New Zealand as well as the whole country. The returns for the country are the average returns of the regions weighted by their populations. ${ }^{4}$ The second and third columns show the annualised mean and volatility of the monthly total returns. On average the New Zealand housing market produces a total return of $11.50 \%$ per year with a volatility of

\footnotetext{
${ }^{3}$ Our momentum, reversal, and value results are all based these formulas, without taking the log of returns. However, when computing the summary statistics for total returns and capital gains in Table 1, which are based on monthly returns, we use log monthly returns.

${ }^{4}$ This is the way REINZ calculates the market returns for the country. This is similar to the stock market indices which are portfolios of individual stocks weighted by their capitalisations.
} 
8.36\%. Across the regions, the average returns per year range from $10.68 \%$ of Canterbury (volatility of $9.90 \%$ ) to $13.29 \%$ of Otago (volatility of $21.05 \%$ ). The statistics for Auckland are similar to those for the whole country, with an average return of $11.48 \%$ and a volatility of $9.60 \%$ per year.

The average capital gains and rental yield per year in New Zealand are $6.07 \%$ and $5.53 \%$, respectively. Across the regions, the average capital gains per year range from $3.68 \%$ in West Coast to $6.61 \%$ in Taranaki. The average rental yield per year ranges from $4.79 \%$ in Taranaki to $7.17 \%$ in West Coast.

The average rent growth rate per year is $4.32 \%$ nationwide. $^{5}$ It ranges from $3.08 \%$ in Manawatu to $4.55 \%$ in Wellington.

\section{F. Other Data}

We use the market risk premium for the New Zealand housing market for adjusting the risk of portfolio returns. For this purpose, we use the 90-day bank bill rate as the risk-free rate. This data is provided by the Reserve Bank of New Zealand. We use the 90-day bank bill rate instead of a one-year government bond yield because there are many periods where the one-year bond yields were discontinued.

\section{Methodology}

At the end of every month from January 1993 to January 2019, we sort regions based on their past returns or current rent-price ratios. The sorted regions are then assigned into one of the four quartile portfolios. Specifically, the four highest ranked regions are placed into Portfolio 4, the next four highest ranked regions are placed into Portfolio 3, and so on. Each region is equally weighted in their assigned quartile portfolios.

When calculating the past returns, we use either the past cumulative capital gains or past cumulative total returns. Total returns are the combination of capital gains and rental yields. The rent-price ratio used for sorting the

${ }^{5}$ The rental growth rate for each month $t$ is calculated as

$$
g_{t}=\log \frac{R_{t}}{R_{t-1}} .
$$

The annual growth rate is the average monthly growth rate within the year multiplied by 12 . 
Table 1-Summary Statistics of the New Zealand Housing Market Returns

\begin{tabular}{|c|c|c|c|c|c|c|}
\hline & \multicolumn{2}{|c|}{ Total Returns } & \multicolumn{2}{|c|}{ Capital Gains } & \multirow{2}{*}{$\frac{\text { Rent Growth }}{\text { Mean }}$} & \multirow{2}{*}{$\frac{\text { Rental Yield }}{\text { Mean }}$} \\
\hline & Mean & Volatility & Mean & Volatility & & \\
\hline$\overline{\text { National }}$ & 11.50 & 8.36 & 6.07 & 8.37 & 4.32 & 5.53 \\
\hline Auckland & 11.48 & 9.60 & 6.55 & 9.60 & 4.10 & 5.02 \\
\hline Bay of Plenty & 11.34 & 14.71 & 6.59 & 14.74 & 4.44 & 4.84 \\
\hline Canterbury & 10.68 & 9.90 & 5.21 & 9.91 & 3.90 & 5.56 \\
\hline Gisborne & 11.41 & 39.95 & 5.28 & 40.05 & 3.97 & 6.24 \\
\hline Hawke's Bay & 11.58 & 16.38 & 6.04 & 16.42 & 4.08 & 5.63 \\
\hline Manawatu & 11.16 & 19.30 & 4.82 & 19.35 & 3.08 & 6.44 \\
\hline Marlborough & 11.00 & 26.47 & 5.80 & 26.53 & 3.79 & 5.28 \\
\hline Nelson & 10.92 & 23.39 & 5.82 & 23.44 & 3.69 & 5.18 \\
\hline Northland & 10.83 & 25.17 & 5.83 & 25.23 & 4.29 & 5.09 \\
\hline Otago & 13.29 & 21.05 & 6.42 & 21.12 & 4.30 & 6.99 \\
\hline Southland & 12.74 & 26.75 & 5.87 & 26.82 & 3.99 & 7.00 \\
\hline Tasman & 11.77 & 23.58 & 5.70 & 23.64 & 3.79 & 6.17 \\
\hline Taranaki & 11.32 & 24.41 & 6.61 & 24.46 & 4.18 & 4.79 \\
\hline Waikato & 11.31 & 11.95 & 6.24 & 11.98 & 4.21 & 5.15 \\
\hline Wellington & 11.25 & 15.77 & 5.61 & 15.80 & 4.55 & 5.74 \\
\hline West Coast & 10.73 & 66.24 & 3.68 & 66.45 & 3.51 & 7.17 \\
\hline
\end{tabular}

Note: This table reports the summary statistics of the housing market returns of the 16 regions of New Zealand as well as the whole country. The second and third columns report the average annual total returns and the volatility. The fourth and fifth columns report the corresponding average annual capital gains and the volatility. The sixth column reports the average annual rent growth. The last column reports the average annual rental yield. The sample is from January 1993 to January 2019. The returns are log returns at monthly frequency. The statistics are in percentage.

regions at the end of month $t$ is calculated as the annualised mean weekly rent divided by the median house price for a region in month $t-1$.

We consider the past returns at two different horizons. First, we examine the returns in the past twelve months for a momentum effect. Second, we examine the returns in the past six years for a long-term reversal effect. When identifying the momentum, we skip the most recent month as that month has a short-term reversal effect due to the microstructure noise in the data. Similarly, when identifying the long-term reversal, we skip the most recent one year. This is to get rid of the momentum effect present in the first year. These considerations are consistent with the practice for the studies of stocks in the literature.

Once the quartile portfolios have been formed, their future performance is recorded. We report the average total returns over time of each portfolio along with the average total returns of the up-minus-down (UMD) (for mo- 
mentum and reversal) or the high-minus-low (HML) (for value) portfolio, which are the returns of Portfolio 4 minus the returns of Portfolio 1. The Newey-West $t$-statistic is used to test if the UMD or HML portfolio has a mean return statistically different from zero. We also decompose future total returns for each year into capital gains and rental yields and test if the differences between the Portfolio 4 and Portfolio 1 are statistically different from zero using the Newey-West $t$-statistic.

In order to test if the UMD and HML portfolios earn risk-adjusted abnormal returns, we run the following time-series regression:

$$
R_{t}=\alpha+\beta\left(R_{t}^{m}-R_{t}^{f}\right)+\epsilon_{t}
$$

where $R_{t}^{f}$ is the return from rolling over the 90-day bank bill rate for one year starting from month $t, R_{t}^{m}$ is the annual housing market total return starting from month $t, R_{t}$ is the annual return for our UMD or HML portfolio starting from month $t$. This is the Capital Asset Pricing Model (CAPM) regression. If the intercept alpha is statistically different from zero, it implies that the UMD and HML portfolios can produce risk-adjusted abnormal returns. We also use the Newey-West $t$-statistic for testing the significance of alpha.

\section{Results}

In this section, we present our empirical findings for the momentum, reversal, and value effects, respectively.

\section{A. Momentum}

Table 2 reports average returns for the four quartile portfolios and the up-minus-down portfolio (UMD) when the regions are sorted based on their past twelve-month cumulative capital gains, skipping the most recent month. After the portfolio formulation date, past winners have outperformed past losers on average by $2.46 \%$ in the following year. This effect is significant at the $1 \%$ level with a $t$-statistic of 3.26 .

The last two columns of Panel A in Table 2 reports the alpha and its $t$-statistic by running a regression of the UMD returns against the housing market risk premium. The alpha of $2.06 \%$ is only slightly smaller than the UMD return and is statistically significantly different from zero at the $5 \%$ 
level with a $t$-statistic of 2.07 . This means that the market risk factor cannot explain the momentum returns generated by the up-minus-down portfolio.

Panels $\mathrm{B}$ and $\mathrm{C}$ of Table 2 report the decomposition of the total return into capital gains and rental yields. The winner portfolio outperforms the loser portfolio by $2.63 \%$ in terms of capital gains, with the magnitude larger than that in terms of the total return. This is because the rental yields go in the opposite direction. Regions which have experienced higher price growths in the past year will earn a $0.28 \%$ lower rental yield in the following year. Both the differences in capital gains and rental yield are statistically significant at the $1 \%$ level.

Table 2-Performance of Portfolios Formed on Past 12-Month Capital GAINS

\begin{tabular}{lcccccccc}
\hline & (Loser) & \multicolumn{7}{c}{ (Winner) } \\
& 1 & 2 & 3 & 4 & UMD & $t(\mathrm{UMD})$ & $\alpha$ & $t(\alpha)$ \\
\hline Past 12-Month & -4.55 & 3.30 & 8.08 & 17.27 & 21.82 & & \\
\hline $\begin{array}{l}\text { Panel A: Total Return } \\
\text { Next Year }\end{array}$ & 11.48 & 11.94 & 13.00 & 13.94 & 2.46 & 3.26 & 2.06 & 2.07 \\
\hline $\begin{array}{l}\text { Panel B: Capital Gains } \\
\text { Next Year }\end{array}$ & 5.14 & 5.93 & 6.97 & 7.77 & 2.63 & 3.74 & \\
$\begin{array}{l}\text { Panel C: Rental Yields } \\
\text { Next Year }\end{array}$ & 5.89 & 5.58 & 5.53 & 5.61 & -0.28 & -3.12 & \\
\hline
\end{tabular}

Note: At the beginning of every month from February 1994 to February 2018, all regions are sorted by their past twelve-month cumulative capital gains, skipping the most recent month, and assigned to one of four quartile portfolios. All regions are equally weighted. Panel A reports the average total returns of each quartile portfolio and the up-minusdown (UMD) portfolio. The average total returns are decomposed into the capital gains and rental yields in Panel B and Panel C, respectively. The Newey-West $t$-statistic is reported. We run a CAPM regression of our UMD total returns against the market risk factor and report the alpha and its $t$-statistic. Returns are in percentage.

Table 3 reports the same statistics when the regions are sorted based on their total returns, instead of just capital gains, in the past twelve months, skipping the most recent month. The results are very similar except that the difference in the rental yield between the past winners and losers becomes statistically insignificant ( $t$-statistic of -1.15$)$. 
Table 3-Performance of Portfolios Formed on Past 12-Month Total ReTURNS

\begin{tabular}{lcccccccc}
\hline & $\begin{array}{c}\text { (Loser) } \\
1\end{array}$ & 2 & 3 & 4 & UMD & $t(\mathrm{UMD})$ & $\alpha$ & $t(\alpha)$ \\
\hline Past 12-Month & 0.68 & 8.76 & 13.79 & 23.68 & 22.99 & & \\
$\begin{array}{l}\text { Panel A: Total Return } \\
\text { Next Year }\end{array}$ & 11.28 & 11.89 & 13.01 & 14.20 & 2.91 & 3.97 & 1.93 & 1.77 \\
$\begin{array}{l}\text { Panel B: Capital Gains } \\
\text { Next Year }\end{array}$ & 5.05 & 5.88 & 6.69 & 7.91 & 2.87 & 4.15 & \\
$\begin{array}{l}\text { Panel C: Rental Yields } \\
\text { Next Year }\end{array}$ & 5.80 & 5.55 & 5.54 & 5.71 & -0.09 & -1.15 & \\
\hline
\end{tabular}

Note: At the beginning of every month from February 1994 to February 2018, all regions are sorted by their past twelve-month cumulative total returns, skipping the most recent month, and assigned to one of four quartile portfolios. All regions are equally weighted. Panel A reports the average total returns of each quartile portfolio and the up-minusdown (UMD) portfolio. The average total returns are decomposed into the capital gains and rental yields in Panel B and Panel C, respectively. The Newey-West $t$-statistic is reported. We run a CAPM regression of our UMD total returns against the market risk factor and report the alpha and its $t$-statistic. Returns are in percentage.

\section{B. Long-term Reversal}

We now provide results when considering the past returns at a longer horizon. Table 4 reports the average returns to the four quartile portfolios as well as the up-minus-down portfolio when the regions are sorted based on their past six-year cumulative capital gains, skipping the most recent year. We can see that the regions which performed poorly in the past six years have performed better in each of the next eight years relative to past winners.

Panel A of Table 4 shows the average total returns for each year after the formation month. In the first year after formation, the loser portfolio outperforms the winner portfolio by $3.16 \%$, which is statistically significant at the $5 \%$ level. The past losers then continue to outperform past winners up to eight years before the $t$-statistic becomes insignificant. The UMD portfolio returns peak at $4.63 \%$ in the fourth year.

However, this UMD portfolio returns can be explained by the market risk factor. The CAPM alpha of the UMD portfolio is not statistically significant for any of the following eight years except for the seventh year.

After decomposing the total returns into the capital gains and rental 
Table 4-Performance of Portfolios Formed on Past Six-Year Capital GAINS

\begin{tabular}{|c|c|c|c|c|c|c|c|c|}
\hline & (Loser) & & & (Winner & & & & \\
\hline & 1 & 2 & 3 & 4 & UMD & $t(\mathrm{UMD})$ & $\alpha$ & $t(\alpha)$ \\
\hline$\overline{\text { Past Six-Year }}$ & 13.47 & 28.19 & 40.33 & 62.81 & 49.35 & & & \\
\hline \multicolumn{9}{|l|}{ Panel A: Total Return } \\
\hline 1st Year & 14.20 & 13.95 & 13.19 & 11.05 & -3.16 & -2.24 & 0.19 & 0.20 \\
\hline 2nd Year & 14.84 & 14.19 & 13.06 & 11.65 & -3.19 & -3.05 & -0.43 & -0.50 \\
\hline 3rd Year & 15.57 & 14.64 & 13.00 & 11.55 & -4.02 & -2.82 & 0.72 & 0.45 \\
\hline 4th Year & 15.84 & 14.77 & 12.82 & 11.21 & -4.63 & -3.34 & -0.43 & -0.29 \\
\hline 5th Year & 14.82 & 12.60 & 12.84 & 10.96 & -3.85 & -4.39 & -1.46 & -1.41 \\
\hline 6th Year & 13.49 & 11.13 & 10.81 & 11.09 & -2.40 & -3.17 & -1.29 & -1.33 \\
\hline 7th Year & 12.15 & 9.83 & 10.18 & 10.00 & -2.15 & -3.02 & -1.22 & -1.93 \\
\hline 8th Year & 10.76 & 10.17 & 9.79 & 9.44 & -1.32 & -1.69 & -0.68 & -0.89 \\
\hline \multicolumn{9}{|l|}{ Panel B: Capital Gains } \\
\hline 1st Year & 7.83 & 8.09 & 7.46 & 5.56 & -2.27 & -1.78 & & \\
\hline 2nd Year & 8.57 & 8.41 & 7.40 & 6.13 & -2.44 & -2.99 & & \\
\hline 3rd Year & 9.41 & 8.41 & 7.40 & 6.05 & -2.44 & -2.92 & & \\
\hline 4th Year & 9.86 & 9.24 & 7.33 & 5.71 & -4.15 & -3.79 & & \\
\hline 5th Year & 9.13 & 7.34 & 7.43 & 5.48 & -3.65 & -5.04 & & \\
\hline 6th Year & 8.04 & 6.02 & 5.58 & 5.63 & -2.41 & -3.27 & & \\
\hline 7th Year & 6.85 & 4.78 & 5.00 & 4.62 & -2.23 & -2.92 & & \\
\hline 8th Year & 5.54 & 5.08 & 4.59 & 4.10 & -1.44 & -1.71 & & \\
\hline \multicolumn{9}{|l|}{ Panel C: Rental Yields } \\
\hline 1st Year & 5.76 & 5.31 & 5.22 & 5.11 & -0.65 & -2.36 & & \\
\hline 2nd Year & 5.62 & 5.21 & 5.17 & 5.12 & -0.51 & -1.17 & & \\
\hline 3rd Year & 5.48 & 5.09 & 5.12 & 5.09 & -0.38 & -1.34 & & \\
\hline 4th Year & 5.30 & 4.95 & 5.02 & 5.10 & -0.20 & -0.73 & & \\
\hline 5th Year & 5.09 & 4.81 & 4.94 & 5.10 & 0.01 & 0.05 & & \\
\hline 6th Year & 4.96 & 4.74 & 4.87 & 5.08 & 0.12 & 0.48 & & \\
\hline 7th Year & 4.88 & 4.74 & 4.86 & 5.05 & 0.16 & 0.60 & & \\
\hline 8th Year & 4.87 & 4.77 & 4.88 & 5.02 & 0.15 & 0.49 & & \\
\hline
\end{tabular}

Note: At the beginning of every month from January 1997 to January 2018, all regions are sorted by their past six-year cumulative capital gains, skipping the most recent year, and assigned to one of four quartile portfolios. All regions are equally weighted. Panel A reports the average total returns of each quartile portfolio and the up-minus-down (UMD) portfolio. The average total returns are decomposed into the capital gains and rental yields in Panel B and Panel C, respectively. The Newey-West $t$-statistic is reported. We run a CAPM regression of our UMD total returns against the market risk factor and report the alpha and its $t$-statistic. Returns are in percentage.

yields, we see in Panel B and Panel C of Table 4 that the reversal is almost entirely driven by the capital gains. The differences in rental yields are small and not statistically significant except for the first year, where the past winners earn a rental yield $0.65 \%$ less than the past losers, and it is statistically significant at the $5 \%$ level.

Table 5 reports the same statistics when the regions are sorted based 
on their total returns, instead of just capital gains, in the past six years, skipping the most recent year. The results are very similar except that the difference in the rental yield between the past winners and losers becomes statistically insignificant even in the first year.

Table 5-Performance of Portfolios Formed on Past Six-Year Total ReTURNS

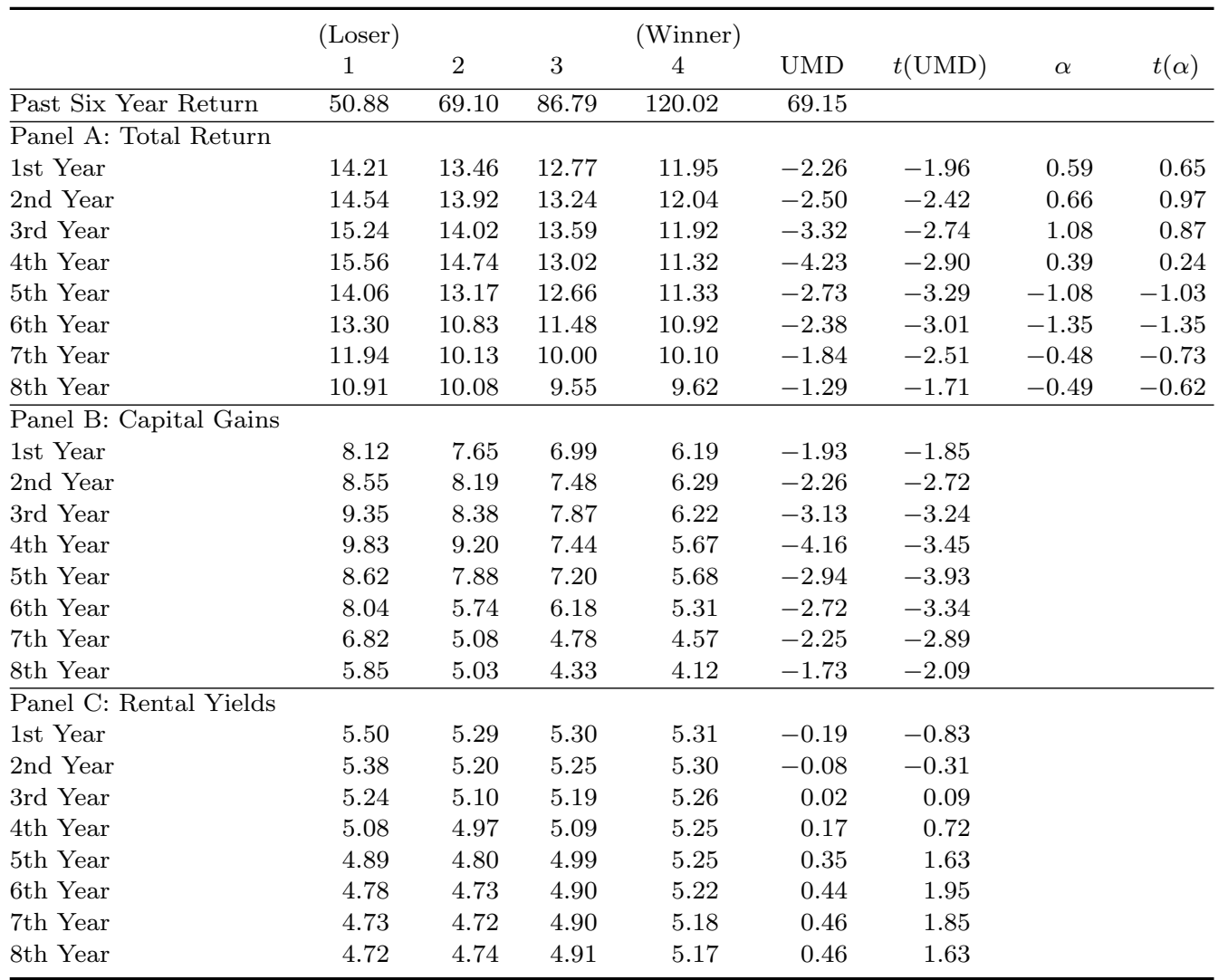

Note: At the beginning of every month from January 1997 to January 2018, all regions are sorted by their past six-year cumulative total returns, skipping the most recent year, and assigned to one of four quartile portfolios. All regions are equally weighted. Panel A reports the average total returns of each quartile portfolio and the up-minus-down (UMD) portfolio. The average total returns are decomposed into the capital gains and rental yields in Panel B and Panel C, respectively. The Newey-West $t$-statistic is reported. We run a CAPM regression of our UMD total returns against the market risk factor and report the alpha and its $t$-statistic. Returns are in percentage. 


\section{Value}

Table 6 shows our results for the value effect. Now forming portfolios based on rent-price ratios one month ago, which are analogous to the earningsprice ratios of stocks, we forecast the cross section of future regional housing market returns. We skip one month because of the short-term one-month reversal arising from noises in the median house prices data.

Panel A shows that portfolios of regions with high rent-price ratios (Value) will outperform portfolios of regions with low rent-price ratios (Growth). First, the economic significance of the differences in returns (HML) is large. The portfolio of regions with the highest rent-price ratios, on average, earns returns $2 \%-3 \%$ higher than that of the portfolio of regions with the lowest rent-price ratios each year. This effect persists up to seven years. These differences in returns are also statistically significant mostly at the $5 \%$ level. However, after adjusting for the market risk, the differences (alpha) between the returns of regions with high and low rent-price ratios are not statistically significant anymore, although they are still positive (last two columns).

Panel B shows that the higher future returns of regions with high rentprice ratios relative to regions with low rent-price ratios are not due to higher capital gains. The differences in capital gains between the returns of regions with high and low rent-price ratios are not statistically significant. Instead, Panel $\mathrm{C}$ shows that regions with high rent-price ratios earn a $1.6 \%-$ $1.9 \%$ higher rental yield than regions with low rent-price ratios each year. The difference persists for many years. These differences in rental yields are highly statistically significant.

Overall, the results imply that regions with high rent-price ratios earn higher returns than regions with low rent-price ratios up to seven years and that these differences are mainly due to the high future rental yields.

Table 7 shows that while the rent-price ratio is persistent, regions do move across the portfolios over time. Nevertheless, a few regions tend to stay in a particular portfolio most of the time. For example, Otago spends over $90 \%$ of the time in the portfolio with the highest rent-price ratios. Portfolios 2 and 3 , however, have significant variations in their members over time. Otago is the only region that has never spent time in Portfolio 2, and Tasman is the only region that has never spent time in Portfolio 3. 
Table 6-Performance of Portfolios Formed on Present Rent-Price Ratio

\begin{tabular}{|c|c|c|c|c|c|c|c|c|}
\hline & (Growth) & & & (Value) & & & & \\
\hline & 1 & 2 & 3 & 4 & HML & $t(\mathrm{HML})$ & $\alpha$ & $t(\alpha)$ \\
\hline Observed Rent-price Ratio & 4.83 & 5.36 & 5.95 & 7.07 & 2.24 & & & \\
\hline \multicolumn{9}{|l|}{ Panel A: Total Return } \\
\hline 1st year & 11.19 & 12.46 & 13.09 & 14.52 & 3.34 & 2.47 & 1.05 & 0.90 \\
\hline 2nd year & 11.33 & 12.19 & 12.78 & 14.06 & 2.73 & 2.08 & 0.52 & 0.46 \\
\hline 3rd year & 11.9 & 12.23 & 12.66 & 13.99 & 2.09 & 1.84 & 1.15 & 1.13 \\
\hline 4th year & 11.70 & 12.38 & 13.03 & 13.68 & 1.97 & 1.65 & 0.29 & 0.29 \\
\hline 5 th year & 11.94 & 11.82 & 12.33 & 14.79 & 2.85 & 2.45 & 1.44 & 1.29 \\
\hline 6 th year & 11.95 & 12.30 & 13.36 & 14.25 & 2.30 & 2.42 & 1.47 & 1.52 \\
\hline 7 th year & 12.44 & 12.41 & 12.86 & 14.77 & 2.33 & 1.82 & 1.55 & 1.57 \\
\hline \multicolumn{9}{|l|}{ Panel B: Capital Gains } \\
\hline 1st year & 5.94 & 6.73 & 6.67 & 7.08 & 1.14 & 0.92 & & \\
\hline 2nd year & 6.09 & 6.54 & 6.44 & 6.73 & 0.65 & 0.53 & & \\
\hline 3rd year & 6.65 & 6.61 & 6.40 & 6.73 & 0.09 & 0.08 & & \\
\hline 4 th year & 6.51 & 6.82 & 6.83 & 6.50 & -0.02 & -0.02 & & \\
\hline 5 th year & 6.77 & 6.35 & 6.25 & 7.63 & 0.86 & 0.78 & & \\
\hline 6 th year & 6.82 & 6.89 & 7.27 & 7.22 & 0.40 & 0.44 & & \\
\hline 7 th year & 7.34 & 7.05 & 6.88 & 7.79 & 0.45 & 0.37 & & \\
\hline \multicolumn{9}{|l|}{ Panel C: Rental Yields } \\
\hline 1st year & 4.87 & 5.27 & 5.88 & 6.77 & 1.90 & 14.46 & & \\
\hline 2nd year & 4.86 & 5.21 & 5.83 & 6.69 & 1.83 & 14.60 & & \\
\hline 3rd year & 4.84 & 5.17 & 5.76 & 6.63 & 1.79 & 14.09 & & \\
\hline 4th year & 4.80 & 5.11 & 5.68 & 6.56 & 1.77 & 13.43 & & \\
\hline 5 th year & 4.76 & 5.05 & 5.61 & 6.49 & 1.73 & 13.34 & & \\
\hline 6 th year & 4.72 & 4.98 & 5.56 & 6.39 & 1.67 & 12.41 & & \\
\hline 7th year & 4.68 & 4.91 & 5.48 & 6.31 & 1.63 & 12.11 & & \\
\hline
\end{tabular}

Note: At the beginning of every month from January 1993 to January 2019, each region of New Zealand is ranked by their rent-price ratio and placed into a quartile portfolio. Each portfolio is an equally weighted average of the regions it is comprised of. We show the average observed rent-price ratio for each quartile portfolio over the sample period. Panel A reports the average total returns of each portfolio within each consecutive year after portfolio formation. The total returns are decomposed into capital gains and rental yields in Panel B and Panel C, respectively. The Newey-West $t$-statistic is reported. We run a CAPM regression of our HML total returns against the market risk factor and report the alpha and its $t$-statistic. Returns are in percentage.

It seems that the Value portfolio most of the time consists of a subset of West Coast, Southland, Otago, Manawatu, Gisborne, and Taranaki, whereas the Growth portfolio most of the time consists of a subset of Auckland, Bay of Plenty, Tasman, Northland, Marlborough, Nelson, and Waikato. However, rebalancing the portfolios is important for our value results. Simply holding a certain fixed group of regions could give very different outcomes from our value results. For example, if we place West 
Table 7 -Frequencies that Regions are Assigned to Different Quartile Portfolios Based on Rent-Price Ratio

\begin{tabular}{lrrrr}
\hline & (Growth) & & & (Value) \\
Region & \multicolumn{1}{c}{2} & \multicolumn{1}{c}{3} & \multicolumn{1}{c}{4} \\
\hline Auckland & 49.36 & 41.67 & 9.29 & 0.00 \\
Bay of Plenty & 83.33 & 16.03 & 0.96 & 0.00 \\
Canterbury & 1.92 & 50.32 & 48.08 & 0.00 \\
Gisborne & 6.41 & 10.90 & 40.38 & 42.63 \\
Hawke's Bay & 4.49 & 36.54 & 56.41 & 2.88 \\
Manawatu & 0.00 & 0.64 & 40.71 & 58.97 \\
Marlborough & 31.73 & 41.35 & 25.96 & 1.28 \\
Nelson & 45.19 & 37.18 & 16.67 & 1.28 \\
Northland & 47.12 & 45.83 & 7.37 & 0.00 \\
Otago & 0.00 & 0.00 & 10.26 & 90.06 \\
Southland & 0.32 & 1.92 & 14.42 & 83.65 \\
Taranaki & 0.32 & 8.97 & 62.82 & 28.21 \\
Tasman & 85.90 & 14.42 & 0.00 & 0.00 \\
Waikato & 41.67 & 52.88 & 5.77 & 0.00 \\
Wellington & 2.24 & 41.03 & 47.12 & 9.94 \\
West Coast & 1.60 & 1.60 & 15.06 & 82.05 \\
\hline
\end{tabular}

Note: This table shows the frequencies (percentages) that each region is assigned to one of the quartile portfolios, from Growth portfolio with the lowest rent-price ratio to the Value portfolio with the highest rent-price ratio, over the 312 portfolio formation months.

Coast, Southland, Otago, and Manawatu into one Value portfolio and Auckland, Bay of Plenty, Tasman, and Northland into a second Growth portfolio, it turns out that the Growth portfolio would have outperformed the Value portfolio by $1.8 \%$ on average per year over the 312 months. Therefore, while regions tend to stay in certain portfolios most of the time, they do move across the portfolios, which drives our value results.

\section{Discussion}

In this section, we discuss the concerns with our results, the implementation, and possible extensions of the analysis. 


\section{A. Maintenance Costs}

We have done robustness checks for all our results by including relative maintenance costs. By setting maintenance costs as a percent of rental income, the overall result does not change. We tested 10\%,15\%,20\%, and $30 \%$ maintenance costs as a percent of rental income. Alphas are reduced in level, but the results are unchanged in their statistical significance and persistence.

We also found momentum and reversal for other time horizons. Momentum can be found when sorting regions based on the past 24-month returns, skipping the most recent month. Long-term reversals are also found when sorting regions on the past 4- or 5-year returns, skipping the most recent year.

\section{B. Illiquidity of the Housing Market}

Liquidity plays an important role in the housing market. The illiquidity of real estate lowers their prices since one requires a higher return to hold an asset with low liquidity. Our analysis ignores this and takes the median price within a region as the representative house value of that region. Moreover, liquidity varies tremendously region by region. For example, Auckland has a days to sale that fluctuates between 30 and 50 days. That for the West Coast however is usually around 90 days but has often fluctuated to as high as 302 days. While our results are interesting on their own, illiquidity is an

important issue that must be dealt with before any investment strategy is implemented based on them.

\section{Fees and Taxes}

In our analysis, we did not take into account the commission fees investors have to pay when selling houses. For investment properties, investors also need to pay the capital gain tax if selling the properties within a period of time (currently five years). So it is impractical to buy and sell houses on a monthly or even annual basis. These frictions will reduce the performance of the investment strategies when implemented in reality. 


\section{Implementation of Strategies}

REITs, which invest in various private and public properties, are popular securities for passive investors wanting exposures to real estate, particularly in the United States. There are a few REITs available to investors in New Zealand, although they are often limited to the entire country or include Australia and other Australasian countries. Another possible way of having exposures to the housing markets of different regions is to trade on the stocks of real estate companies.

\section{E. Occupation Rates}

Another important consideration when investing directly in real estate is the occupation rates. If you own a property and wish to rent it out, it is not guaranteed to always have people renting throughout the year. Moreover, fixed-term tenancies are often for 12-24 months in New Zealand. So shortterm returns for regions with high rent growth might have been overstated in our analysis.

\section{Conclusion}

This paper identifies momentum, reversal, and value effects in the cross section of New Zealand regional housing markets. Regions that outperformed other regions in the past year will continue to outperform those same regions for one year. Regions that performed relatively poorly over the past six years will instead outperform past winners over the next eight years. Differences in regional housing performance can also be explained by the rent-price ratio. Regions with high rent-price ratios outperform regions with low rent-price ratios up to seven years. These findings are consistent with the previous research into stocks, bonds, currency, and commodities for various markets around the world.

We find that the momentum effect cannot be explained by the housing market risk, while the reversal and value effects are likely due to the housing market risk. Future work should be directed towards other pricing effects such as size and liquidity. It is also important to extend the research beyond regions and see whether similar patterns exist across suburbs. 


\section{REFERENCES}

Addae-Dapaah, K., Webb, J. R., Ho, D. K. H., and Liow, K. H. (2013). Value versus growth international real estate investment. Real Estate Economics, 41(1), 65-101.

Barberis, N., Shleifer, A., and Vishny, R. (1998). A model of investor sentiment. Journal of Financial Economics, 49(3), 307-343.

Asness, C. S., Moskowitz, T. J., and Pedersen, L. H. (2013). Value and momentum everywhere. Journal of Finance, 68(3), 929-985.

Basu, S. (1983). The relationship between earnings' yield, market value and return for NYSE common stocks: Further evidence. Journal of Financial Economics, 12(1), 129-156.

Beracha, E., and Skiba, H. (2013). Findings from a cross-sectional housing risk-factor model. Journal of Real Estate Finance and Economics, 47(2), 289-309.

Beracha, E., and Downs, D. H. (2015). Value and momentum in commercial real estate: A market-level analysis, Journal of Portfolio Management Special Real Estate Issue, 41(6), 48-61.

Beracha, E., Downs, D. H., and MacKinnon, G. (2017). Are high-cap-rate properties better investments? Journal of Portfolio Management Special Real Estate Issue, 43(6), 162-178.

Campbell, J. Y., and Shiller, R. J. (1988). The dividend-price patio and expectations of future dividends and discount factors. Review of Financial Studies, 1(3), 195-228.

Chan, L. K., Jegadeesh, N., and Lakonishok, J. (1996). Momentum strategies. Journal of Finance, 51(5), 1681-1713.

Chui, A. C., Titman, S., and Wei, K. J. (2003). The cross section of expected REIT returns. Real Estate Economics, 31(3), 451-479.

De Bondt, W. F., and Thaler, R. (1985). Does the stock market overreact? Journal of finance, 40(3), 793-805.

De Bondt, W. F., and Thaler, R. H. (1987). Further evidence on investor overreaction and stock market seasonality. Journal of finance, 42(3), 557581.

Derwall, J., Huij, J., Brounen, D., and Marquering, W. (2009). REIT 
momentum and the performance of real estate mutual funds. Financial Analysts Journal, 65(5), 24-34.

Fama, E. F., and French, K. R. (1992). The cross-section of expected stock returns. Journal of Finance, 47(2), 427-465.

Fama, E. F., and French, K. R. (1996). Multifactor explanations of asset pricing anomalies. The Journal of Finance, 51(1), 55-84.

Gallin, J. (2008). The long-run relationship between house prices and rents. Real Estate Economics, 36(4), 635-658.

Greenaway-McGrevy, R., Grimes, A., and Holmes, M. (2019). Two countries, sixteen cities, five thousand kilometres: How many housing markets? Papers in Regional Science, 98(1), 353-370.

Greenaway-McGrevy, R., and Phillips, P. C. B. (2016). Hot property in New Zealand: Empirical evidence of housing bubbles in the metropolitan centres. New Zealand Economic Papers, 50(1), 88-113.

Grimes, A., Holmes, M., and Tarrant, N. (2010). New Zealand housing markets: Just a bit-player in the A-league? Motu Working Paper 10-07, Wellington: Motu.

Hall, V., McDermott, J., and Tremewan J. (2006). The ups and downs of New Zealand house prices. Motu Working Paper 06-03, Wellington: Motu.

Hung, S. Y. K., and Glascock, J. L. (2008). Momentum profitability and market trend: Evidence from REITs. Journal of Real Estate Finance and Economics, 37(1), 51-69.

Jegadeesh, N., and Titman, S. (1993). Returns to buying winners and selling losers: Implications for stock market efficiency. Journal of Finance, 48(1), 65-91.

Liu, C. H., and Mei, J. (1992). The predictability of returns on equity REITs and their co-movement with other assets. Journal of Real Estate Finance and Economics, 5(4), 401-418.

Mei, J. J., and Liu, C. H. (1994). The predictability of real estate returns and market timing. Journal of Real Estate Finance and Economics, 8(2): 115-135.

Plazzi, A., Torous, W., and Valkanov, R. (2010). Expected returns and expected growth in rents of commercial real estate. Review of Financial 
Studies, 23(9), 3469-3519. 